\title{
Review of modelling energy transitions pathways with application to energy system flexibility
}

Bolwig, Simon; Bazbauers, Gatis; Klitkou, Antje; Lund, Peter ; Blumberga, Andra; Gravelsins, Armands; Blumberga, Dagnija

\section{Published in:}

Renewable and Sustainable Energy Reviews

Link to article, DOI:

10.1016/j.rser.2018.11.019

Publication date:

2019

Document Version

Peer reviewed version

Link back to DTU Orbit

Citation (APA):

Bolwig, S., Bazbauers, G., Klitkou, A., Lund, P., Blumberga, A., Gravelsins, A., \& Blumberga, D. (2019). Review of modelling energy transitions pathways with application to energy system flexibility. Renewable and

Sustainable Energy Reviews, 101, 440-452. https://doi.org/10.1016/j.rser.2018.11.019

\section{General rights}

Copyright and moral rights for the publications made accessible in the public portal are retained by the authors and/or other copyright owners and it is a condition of accessing publications that users recognise and abide by the legal requirements associated with these rights.

- Users may download and print one copy of any publication from the public portal for the purpose of private study or research.

- You may not further distribute the material or use it for any profit-making activity or commercial gain

- You may freely distribute the URL identifying the publication in the public portal 


\title{
Review of modelling energy transitions pathways with application to energy system flexibility
}

\author{
Simon Bolwig ${ }^{\mathrm{a}, *}$, Gatis Bazbauers ${ }^{\mathrm{b}}$, Antje Klitkou ${ }^{\mathrm{c}}$, Peter D. Lund ${ }^{\mathrm{d}}$, Andra Blumberga ${ }^{\mathrm{b}}$, Armands Gravelsins $^{\mathrm{b}}$, \\ Dagnija Blumberga ${ }^{\mathrm{b}}$ \\ a Technical University of Denmark, Department of Management Engineering, Produktionstorvet 426, Kongens Lyngby DK-2800, Denmark \\ ${ }^{\mathrm{b}}$ Riga Technical University, Faculty of Power and Electrical Engineering, Institute of Energy Systems and Environment, Azenes 12/1 Street, Riga LV-1048, Latvia \\ ${ }^{\mathrm{c}}$ Nordic Institute for Studies in Innovation, Research and Education, PO Box 2815 Tøyen, NO-0608 Oslo, Norway \\ d Aalto University, School of Science, PO Box 15100, FI-00076 Aalto, Espoo, Finland
}

\section{A R T I C L E I N F O}

\section{Keywords:}

Transitions pathways

Socio-technical factors

Sustainable energy systems

Energy system modelling

System dynamics modelling

Energy system flexibility

\begin{abstract}
A B S T R A C T
The aim of this review is to discuss how quantitative modelling of energy scenarios for sustainable energy transition pathways can be made more realistic by taking into account insights from the socio-technical and related literatures. The proposition is that an enriched modelling approach would focus not just on technology development and deployment, but also on feedback loops, learning processes, policy and governance, behavioural changes, the interlinkages between the energy sector and other economic sectors, and infrastructure development. The review discusses a range of socio-technical concepts with a view to how they can enrich the understanding and modelling of highly complex dynamic systems such as flexible energy systems with high shares of variable renewable energy. In this context, application of system dynamics modelling (SDM) for the analysis of energy transitions is also introduced by describing the differences between SDM and a traditional modelling approach that uses econometric and linear programming methods. A conceptual framework for this type of modelling is provided by using causal loop diagrams. The diagrams illustrate the endogenous approach of SDM understanding and modelling the structure of a system, which is responsible for its dynamic behaviour. SDM can also capture the co-evolution of economic, policy, technology, and behavioural factors over sufficiently long time periods, which is necessary for the analysis of transition pathway dynamics. In this regard, the review summarises how socio-technical concepts can be approached in SDM and why they are relevant for the analysis of flexibility in energy systems. From a computational point of view, it could be beneficial to combine SDM with technologically detailed energy system optimization models and that could be a way forward for achieving more realistic, non-linear quantitative modelling of sustainable energy transitions.
\end{abstract}

\section{Introduction}

To respond to the climate change mitigation quest, massive amounts of clean energy need to be introduced in the coming decades. The magnitude of the changes needed to meet the targets of the Paris Climate Accord from December 2015 represents a major transition from the present fossil-fuel based energy economy to a clean-energy one, which is almost $\mathrm{CO}_{2}$ free. The changes ahead are not only about technology changes, but include major societal changes as well turning the changes into a major social-technical transition.
This review adds to the literature to better understand and model the transition from the present energy system to a sustainable one in line with the ambitious climate goals [1]. Two strands of literature on energy transitions have evolved in parallel. The first deals with socio-technical analyses of energy transitions including transition pathways [2-5]. The second one is on quantitative modelling of energy systems on a macro scale using integrated assessment models that address multiple societal objectives [6], agent-based modelling of complex systems $[7,8]$, or technologically detailed energy system optimization models such as ETP-TIMES [9] and Balmorel [10]. Some recent studies [11-13] also discuss the ways of integrating or bridging the two distinct analytical approaches, often labelled as 'socio-technical' and 'techno-eco-

\footnotetext{
* Corresponding author.

Email addresses: sibo@dtu.dk (S. Bolwig); gatis.bazbauers@rtu.lv (G. Bazbauers); antje.klitkou@nifu.dk (A. Klitkou); peter.lund@aalto.fi (P.D. Lund); andra.blumberga@rtu.lv (A. Blumberga); armands.gravelsins@rtu.lv (A. Gravelsins); dagnija.blumberga@rtu.lv (D. Blumberga)
} 
Table 1

Analytical challenges for studying sustainability transitions (adapted from [18])

\begin{tabular}{|c|c|c|c|}
\hline Factor & $\begin{array}{l}\text { Socio-technical } \\
\text { transition } \\
\text { analysis }\end{array}$ & $\begin{array}{l}\text { Initiative-based } \\
\text { learning }\end{array}$ & $\begin{array}{l}\text { Quantitative } \\
\text { systems } \\
\text { modelling }\end{array}$ \\
\hline $\begin{array}{l}\text { Focus on } \\
\text { transition } \\
\text { pathways }\end{array}$ & $\begin{array}{l}\text { Historically } \\
\text { informed } \\
\text { perspective }\end{array}$ & $\begin{array}{l}\text { Micro-perspective } \\
\text { on local-scale } \\
\text { projects and } \\
\text { upscaling }\end{array}$ & $\begin{array}{l}\text { Future-oriented } \\
\text { perspective on } \\
\text { transitions }\end{array}$ \\
\hline $\begin{array}{l}\text { Handling of } \\
\text { complexity } \\
\text { and } \\
\text { uncertainty }\end{array}$ & $\begin{array}{l}\text { Uses pathway } \\
\text { typologies as } \\
\text { theoretical } \\
\text { constructs and } \\
\text { analytical devices }\end{array}$ & $\begin{array}{l}\text { In-depth case } \\
\text { studies, but limited } \\
\text { focus on predictions }\end{array}$ & $\begin{array}{l}\text { Relatively } \\
\text { constrained by } \\
\text { fixed initial } \\
\text { system } \\
\text { boundaries and } \\
\text { structures }\end{array}$ \\
\hline $\begin{array}{l}\text { Addressing } \\
\text { inertia and } \\
\text { path } \\
\text { dependence }\end{array}$ & $\begin{array}{l}\text { Inertia as outcome } \\
\text { of structural } \\
\text { resilience of the } \\
\text { dominant regime }\end{array}$ & $\begin{array}{l}\text { Inertia as preference } \\
\text { of powerful actors } \\
\text { under pressure } \\
\text { (central energy } \\
\text { supply and } \\
\text { distribution, } \\
\text { persistence of fossil } \\
\text { fuels subsidies) }\end{array}$ & $\begin{array}{l}\text { Inertia as techno- } \\
\text { economic } \\
\text { constraints, like } \\
\text { sunk investments }\end{array}$ \\
\hline $\begin{array}{l}\text { Multiple } \\
\text { normative } \\
\text { goals of } \\
\text { transitions }\end{array}$ & $\begin{array}{l}\text { Linkage of } \\
\text { sustainability } \\
\text { goals with other } \\
\text { policy priorities }\end{array}$ & $\begin{array}{l}\text { Activist-orientation } \\
\text { and normative } \\
\text { positions }\end{array}$ & $\begin{array}{l}\text { Economic } \\
\text { considerations } \\
\text { serve as a } \\
\text { rationale for } \\
\text { sustainable } \\
\text { actions }\end{array}$ \\
\hline $\begin{array}{l}\text { Variety of } \\
\text { perspectives } \\
\text { on } \\
\text { governing } \\
\text { transitions }\end{array}$ & $\begin{array}{l}\text { Insights from } \\
\text { historical } \\
\text { transformations } \\
\text { can inform and } \\
\text { focus current } \\
\text { transition efforts, } \\
\text { but less useful for } \\
\text { future scenarios }\end{array}$ & $\begin{array}{l}\text { Insights on local } \\
\text { alternatives, but } \\
\text { limited attention to } \\
\text { interaction with } \\
\text { regime trajectories } \\
\text { and to link to } \\
\text { broader } \\
\text { transformations }\end{array}$ & $\begin{array}{l}\text { Can assist } \\
\text { decision-making } \\
\text { for long-term } \\
\text { policy targets, but } \\
\text { less useful for } \\
\text { considering } \\
\text { institutional and } \\
\text { social inertia }\end{array}$ \\
\hline
\end{tabular}

nomic'. They address the former one's focus on socio-technical variables (institutions, actors, values, technology innovation, etc.) and their interaction over longer time periods (decades) at multiple levels and scales. The latter one emphasises detailed technological and economic variables, and system interactions, also over decades, in a formalised quantitative framework.

In addition to these two main approaches, there exist alternative perspectives identified by [12] and by [13]. The first article highlights the initiative-based learning approach that stresses the influence of transition pathways of real-world experimentation, learning by doing, actor involvement, stakeholder relevance, and local level implementation. The latter identifies political perspectives that address the role of institutions, the state, international relations, and special interests, among other political economic factors.

In the light of these recent advances, and to add new insights, this paper aims at analysing how quantitative modelling of energy scenarios as sustainable energy transition pathways can be made more realistic and less linear, accounting for insights from the socio-technical and related literature above. The proposition is that an enriched modelling approach should not focus just on technology development and deployment, but also on feedback loops, learning processes, the importance of policy and governance and of behavioural changes, interlinkages between the energy and other economic sectors, and infrastructure development.

We link our analysis in particular to variable renewable electricity generation (VRE) such as wind and solar power, which are the key energy production technologies in the clean energy transition [14]. We focus on the Nordic region, in which wind energy may play a more important role than on average globally, which may also introduce major challenges with balancing the power system demand and supply. The technological quest may therefore not only be in the clean energy production, but actually in approaches, which increase the flexibility of the whole energy system so that the power demand and supply are matched and that the energy system can accept clean power. This in turn indicates a major systemic change in the energy system as well. We consider increasing the flexibility of the energy system as an important element in the energy transition $[15,16]$ and as an important enabler of the transition, for which reason it is also given attention in our analysis.

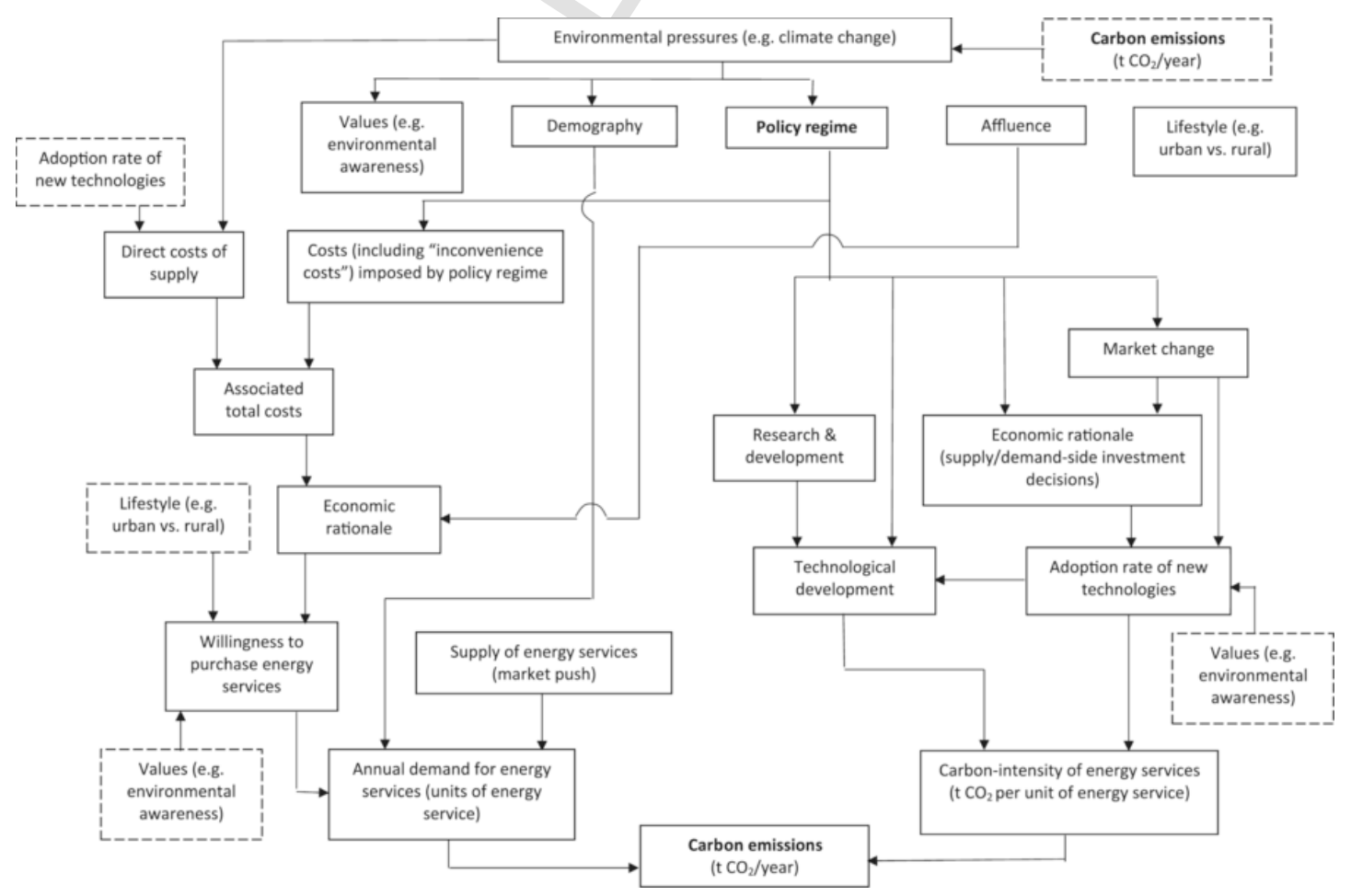

Fig. 1. Example of elements of the system dynamics model (SDM) representing the socio-technical energy transition with focus on the environmental drivers. 


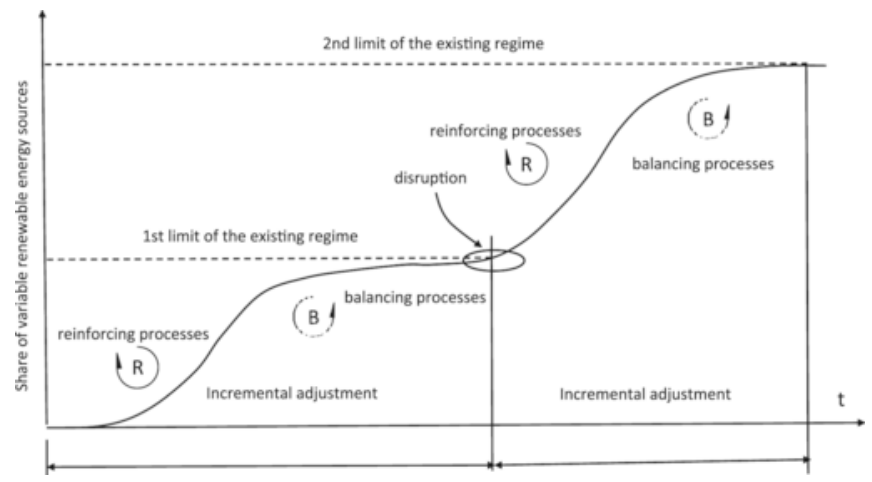

Fig. 2. Dynamics of share of variable renewable energy sources as portrayed by interaction of reinforcing and balancing processes and disruption.

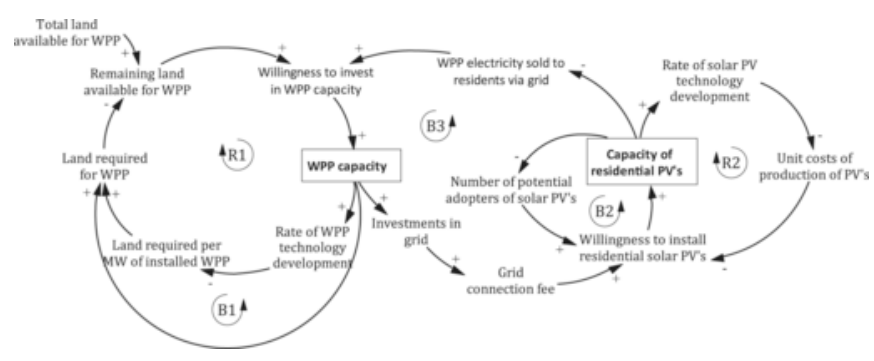

Fig. 3. Dynamic model of interaction between wind power and residential photovoltaics (PV) capacity; $\mathrm{R}=$ reinforcing loop, $\mathrm{B}=$ balancing loop, $\mathrm{WPP}=$ wind power plant, $\mathrm{PV}=$ photovoltaics. "' sign on the arrow means that cause and effect move in the same direction (i.e. if cause increases, the effect will increase as well, and vice versa). "-" sign means that cause and effect move in opposite directions (i.e. if cause increases, the effect will decrease, and vice versa).

Finally, the review will also provide an assessment on how well quantitative modelling approaches other than integrated assessment models and optimization energy models are suited to consider socio-technical variables and deal with highly complex dynamic systems [11]. The focus here is on system dynamics modelling (SDM) [17]. Application of system dynamics for modelling of energy transitions is analysed by describing the differences between system dynamics and a traditional modelling approach that uses econometric and linear programming methods. A conceptual framework, represented by causal relations between elements of a system for this type of modelling is provided in Section 5.
The remainder of the paper is organised as follows. The next section outlines different theoretical perspectives on energy transitions and the analytical challenges associated with each one, and states the research questions. Section 3 describes the different steps of the methodology developed in the paper and outlines the main elements in system dynamics modelling of sustainable energy transitions. Section 4 discusses concepts from the sustainable transitions literature that we find relevant for understanding and modelling energy transition pathways. Section 5 highlights the unique features of SDM and how this approach differs from traditional energy modelling tools. We then discuss how SDM can be applied to the case of flexibility in an energy system with high shares of variable renewable energy. Finally, we assess the concepts discussed in Section 4 - in terms of their use in SDM for energy transitions pathways and regarding their relevance for analysing energy system flexibility in general. Section 6 concludes the paper and identifies areas for future research.

\section{Background to understanding energy transition pathways}

Energy transitions have been studied from different theoretical perspectives [12,13]. Such transitions have to be understood as co-evolution of three distinct systems: (1) techno-economic systems characterized by energy flows like energy production, conversion, and consumption coordinated by the energy markets, (2) socio-technical systems defined by the energy technologies embedded in their socio-technical context, and (3) systems of political actions influencing formulation and implementation of energy policies [13]. These three systems co-evolve and have different boundaries. They are semi-autonomous, but changes are mutually interdependent, which means that the interaction of all three systems must be addressed to fully understand the energy transition processes. [13] distinguished between three main theoretical perspectives addressing these three systems: (1) economic and energy system analysis for studying the techno-economic system, (2) sociology and history of technology, evolutionary economics, for studying socio-technical systems, and (3) political science and political economy for studying systems of political actions.

Quantitative modelling of energy transition pathways (or energy-economic systems) traditionally draws on the techno-economic perspective, which focuses on "energy systems defined by energy flows, conversion processes, and consumption coordinated through the energy markets" [13] and relies on theories from earth sciences, engineering and economics (ibid). The quantitative systems modelling approach in this theoretical perspective has limitations when considering the behaviour of the actors, the role of inertia and innovation and also ex-

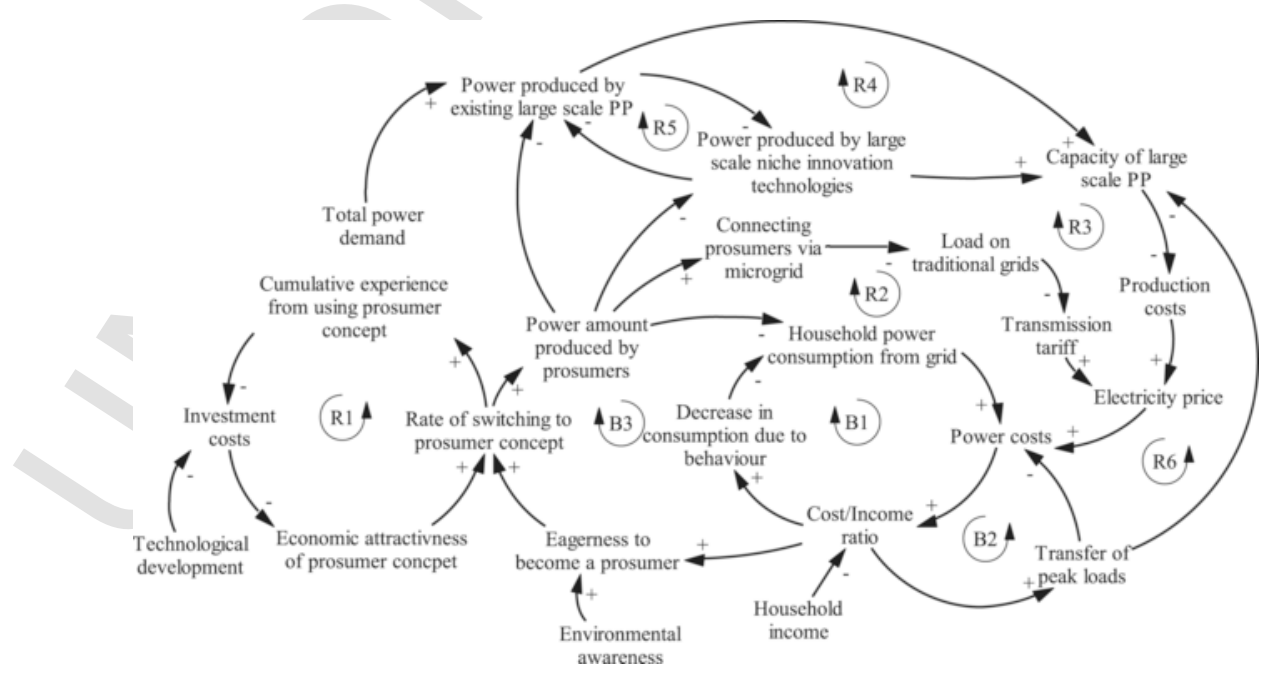

Fig. 4. Dynamic model of interaction between centralized and de-centralized power producers and consumers. $\mathrm{PP}=$ power plant; $\mathrm{R}=$ reinforcing loop; $\mathrm{B}=$ balancing loop. 


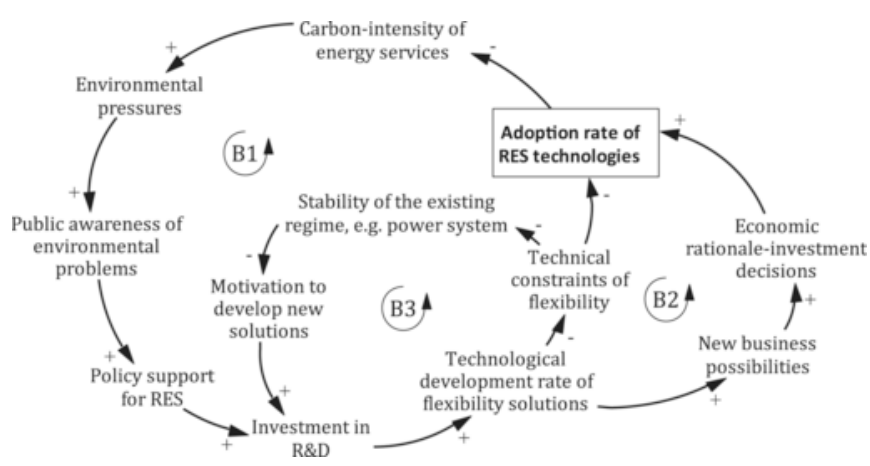

Fig. 5. Causal loop diagram illustrating balancing effects caused by changes in the adoption rate of renewable energy source (RES) technologies with a focus on flexibility.

plaining the spatial dimension of energy transitions [13]. [12] distinguish between three theoretical approaches to sustainability transitions: socio-technical transition analysis, initiative-based learning, and quantitative systems modelling. They highlight five analytical challenges to study sustainability transitions: (1) transformation processes forego at different socio-spatial scales and over extended periods of time and a comprehensive understanding of transition pathways requires a thorough understanding of the past, the present, and the future, but here the different approaches have different assumptions for studying these; (2) innovation dynamics is very complex and difficult to predict, but policy support has to comprehend the timing and possible changes of policy interventions and to take into account innovation dynamics; (3) sustainability transitions have to overcome inertia and path dependence, but these are captured differently by different approaches; (4) normative goals of sustainability transitions have to balance with other objectives, like economic competitiveness, human health, and security, (5) a variety of perspectives on governing transitions calls for more integrated perspectives. These analytical challenges are summarised in Table 1.

Here we also pay attention to methodological challenges to achieving more flexibility in the Nordic energy system as a key component of a clean energy transition. Flexibility is one of the critical pre-conditions for integration of variable renewable energy sources such as wind and solar. Flexibility measures include both demand and supply side measures such as demand side management (DSM), energy storage, power-to-heat and power-to-gas coupling, power curtailment, etc. [19]. When dealing with such enabling technologies it is necessary to integrate mainstream clean energy options together to provide a functioning sustainable energy production system. It requires approaches that are more versatile. For this purpose, the paper will also discuss system dynamics modelling (SDM) as a tool for quantitative systems modelling. We address analytical challenges related to (a) future oriented transition pathways and (b) how complexity and uncertainty can be handled in the system boundaries, and (c) how path dependence and lock-ins are to be addressed.

With this as background, the paper will address the following research questions:

How can the understanding and modelling of energy transitions pathways be improved through consideration or integration of variables and insights drawn from the socio-technical perspective, especially regarding energy system issues related to flexibility?

How can SDM integrate socio-technical variables in light of its unique features compared to traditional modelling approaches? How can flexibility of the energy system be represented in SDM?

\section{Material and methods}

The study builds on a review of articles from the literatures on sustainability transitions and system dynamics. The material was reviewed
Table 2

Integration of sustainable transitions concepts in system dynamics modelling.

\begin{tabular}{|c|c|c|}
\hline ST concept & Approach in system dynamics models & $\begin{array}{l}\text { Relevance for } \\
\text { analysis of } \\
\text { flexibility }\end{array}$ \\
\hline \multicolumn{3}{|l|}{ Transitions pathways } \\
\hline $\begin{array}{l}\text { Transformation } \\
\text { pathway }\end{array}$ & $\begin{array}{l}\text { Endogenously represented by co-evolving } \\
\text { stocks and flows (S\&F) portraying } \\
\text { technology and competence development } \\
\text { processes. }\end{array}$ & $\begin{array}{l}\text { Development of } \\
\text { competences } \\
\text { required for } \\
\text { adoption and } \\
\text { use of } \\
\text { automation } \\
\text { systems of } \\
\text { home } \\
\text { appliances } \\
\text { which allow to } \\
\text { shift peak load } \\
\text { and increase } \\
\text { consumption at } \\
\text { certain periods } \\
\text { of time. }\end{array}$ \\
\hline $\begin{array}{l}\text { Reconfiguration } \\
\text { pathway }\end{array}$ & $\begin{array}{l}\text { Development of novel technologies and } \\
\text { their incorporation into existing system } \\
\text { represented by co-evolving S\&F. The } \\
\text { novel technological solutions gradually } \\
\text { overtake existing solutions when a certain } \\
\text { maturity is reached. }\end{array}$ & $\begin{array}{l}\text { Digitalization, } \\
\text { development of } \\
\text { demand-side } \\
\text { response } \\
\text { technologies } \\
\text { and solutions, } \\
\text { incl. new } \\
\text { linkages } \\
\text { between } \\
\text { established } \\
\text { utilities and ICT } \\
\text { companies in } \\
\text { e.g. smart grid } \\
\text { development, } \\
\text { smart meter } \\
\text { apps etc. }\end{array}$ \\
\hline $\begin{array}{l}\text { Technological } \\
\text { substitution } \\
\text { pathway }\end{array}$ & $\begin{array}{l}\text { Technological choice can be based on } \\
\text { unit costs of production which includes } \\
\text { direct costs of production and } \\
\text { "'inconvenience costs" which reflect } \\
\text { pressure from new solutions. }\end{array}$ & $\begin{array}{l}\text { Development of } \\
\text { electric } \\
\text { vehicles, which } \\
\text { provide } \\
\text { flexibility } \\
\text { solutions, } \\
\text { especially } \\
\text { vehicle-to-grid } \\
\text { systems. } \\
\text { Decision of car } \\
\text { producers to } \\
\text { gradually stop } \\
\text { production of } \\
\text { gasoline cars } \\
\text { may represent } \\
\text { "inconvenience } \\
\text { costs" for new } \\
\text { car buyers. }\end{array}$ \\
\hline $\begin{array}{l}\text { De-alignment and } \\
\text { re-alignment } \\
\text { pathway }\end{array}$ & $\begin{array}{l}\text { A system model built with SDM can be } \\
\text { tested by applying exogenous shocks to it } \\
\text { but these shocks cannot be modelled } \\
\text { endogenously since these are external to } \\
\text { the system. }\end{array}$ & $\begin{array}{l}\text { Fast } \\
\text { development of } \\
\text { large, energy- } \\
\text { intensive } \\
\text { industrial sector } \\
\text { due to external } \\
\text { factors, which } \\
\text { can provide } \\
\text { considerable } \\
\text { demand } \\
\text { flexibility. }\end{array}$ \\
\hline $\begin{array}{l}\text { Strategic niche } \\
\text { management }\end{array}$ & $\begin{array}{l}\text { Driver of technological and institutional } \\
\text { disruption (e.g. the balancing loop B3 in } \\
\text { Fig. 5). Development of complementary } \\
\text { technologies and infrastructures, } \\
\text { supporting technology diffusion portrayed } \\
\text { as co-flows. }\end{array}$ & $\begin{array}{l}\text { Development of } \\
\text { cold storage for } \\
\text { freezers in } \\
\text { order to use } \\
\text { cooling } \\
\text { equipment } \\
\text { flexibly. }\end{array}$ \\
\hline
\end{tabular}


Table 2 (Continued)

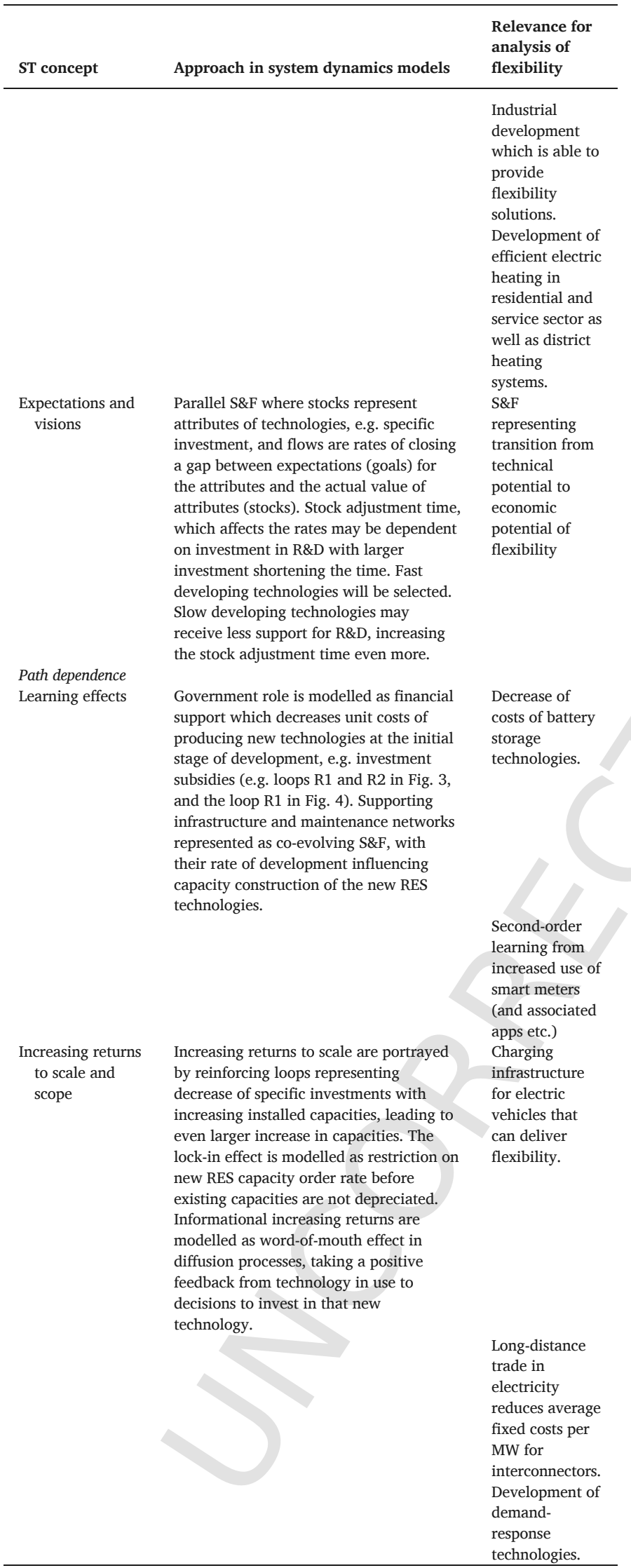

Table 2 (Continued)

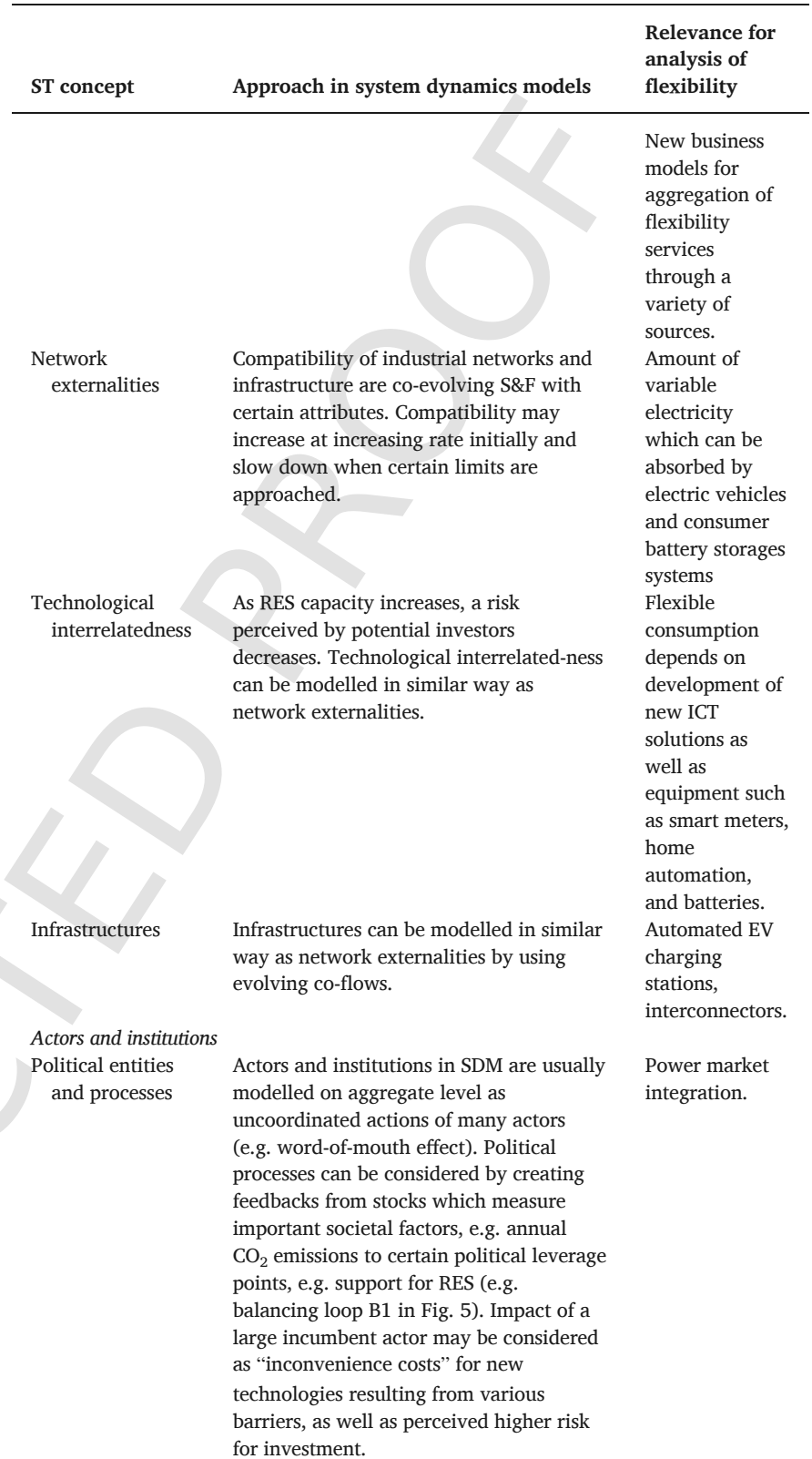

Introduction of

new market mechanisms and national regulation and legislation.

Political support to tax reforms to promote a flexible energy system, including electrification of heating and transport. Capacity of state agencies to give direction and to implement policies. 
Table 2 (Continued)

\begin{tabular}{|c|c|c|}
\hline ST concept & Approach in system dynamics models & $\begin{array}{l}\text { Relevance for } \\
\text { analysis of } \\
\text { flexibility }\end{array}$ \\
\hline & & $\begin{array}{l}\text { Coordination of } \\
\text { governance } \\
\text { processes. } \\
\text { Effect of EU } \\
\text { energy policy } \\
\text { on flexibility- } \\
\text { enabling } \\
\text { policies in } \\
\text { member states. }\end{array}$ \\
\hline \multirow[t]{2}{*}{$\begin{array}{l}\text { Strategic actions } \\
\text { of core industry } \\
\text { actors }\end{array}$} & $\begin{array}{l}\text { Activities of core industry actors which } \\
\text { hamper development of new technologies } \\
\text { create "inconvenience costs" for new } \\
\text { technologies. Activities which lead to } \\
\text { faster development and diffusion of new } \\
\text { technologies may be modelled similarly } \\
\text { to learning effects. }\end{array}$ & $\begin{array}{l}\text { Alignment } \\
\text { between } \\
\text { companies' and } \\
\text { institutions' } \\
\text { strategies. }\end{array}$ \\
\hline & & $\begin{array}{l}\text { Investments in } \\
\text { flexibility } \\
\text { enabling } \\
\text { technologies, } \\
\text { such as electric } \\
\text { vehicles, } \\
\text { battery storage. } \\
\text { Decisions of } \\
\text { large utilities to } \\
\text { engage in } \\
\text { flexibility } \\
\text { services. } \\
\text { Industry } \\
\text { lobbying of } \\
\text { energy policies. }\end{array}$ \\
\hline $\begin{array}{l}\text { Consumer } \\
\text { behaviour and } \\
\text { values }\end{array}$ & $\begin{array}{l}\text { Modelled similarly to political entities } \\
\text { and processes, as uncoordinated actions } \\
\text { of many actors. Development of prosumer } \\
\text { sector in Figs. } 3 \text { and } 4 \text { depends on } \\
\text { economic factors but this process may be } \\
\text { modelled also as dependent from } \\
\text { consumer values. Feedback from } \\
\text { environmental problems associated with } \\
\text { energy production from fossil resources } \\
\text { increases environmental awareness which } \\
\text { increases motivation to install solar PVs. }\end{array}$ & $\begin{array}{l}\text { Social } \\
\text { acceptance of } \\
\text { flexible } \\
\text { consumption to } \\
\text { further VRE } \\
\text { integration. }\end{array}$ \\
\hline & & $\begin{array}{l}\text { Values } \\
\text { supporting } \\
\text { decentralised } \\
\text { vs. centralised } \\
\text { energy supply. } \\
\text { Consumer } \\
\text { acceptance of } \\
\text { electric vehicles } \\
\text { and air } \\
\text { pollution from } \\
\text { ICEs. }\end{array}$ \\
\hline
\end{tabular}

to develop a conceptual and methodological framework rather than providing a comprehensive assessment of the literature. Special focus was placed on endogenous reinforcing and balancing mechanisms responsible for transition dynamics.

The study demonstrates a conceptual approach, which can be used for quantitative modelling of energy transition process that takes into account economic, technological, as well as socio-technical factors. We propose system dynamics modelling as an appropriate method for addressing challenges that arise in quantitative modelling of socio-technical factors and their complex interrelations over relatively long-time horizons. Therefore, the methodology contains the following steps:

1. Definition of the dynamic problem, which must be addressed by the modelling;

2. Statement of the goal of the modelling as derived by the dynamic problem and corrective actions sought;
3. Creation of the dynamic hypothesis regarding the structure of the studied system, which is responsible for causing the dynamic problem;

4. Representing the structure proposed by the dynamic hypothesis as a quantitative model built as a set of stocks, flows and parameters;

5. Validation of the model and simulation of the reference case;

6. Policy test aiming at altering the problematic behaviour of the system by simulating the result of changed values of the most influential parameters - leverage points, or alteration of the system's structure;

7. Policy implementation testing consequences of realization of the modelled solutions in real life applications.

The present study accomplished steps one to three and the results can be used for creating a quantitative model based on stocks and flows.

The dynamic problem was stated as follows: a rate of progress towards the wider goal of deep decarbonisation (of economy in general and energy sector in particular) remains slow. Therefore, the goal of modelling was to find potential dynamics of decarbonisation considering the factors, which are the most critical for the process and possible values of these factors. The key factors driving the decarbonisation of energy systems are environmental pressures, security of supply, and economy (affordability). With point of departure in one of these drivers, environmental pressures, Fig. 1 shows the prominent factors including economy, demography, technology, values, and policy - that link this driver (top of the figure) with carbon emissions from energy systems (bottom of the figure). The model should allow us to test policy scenarios, which consider various impacts on these factors. These factors should be simulated in the model as the parameters - leverage points, affecting flows, which in turn alter stocks serving as a measurement gauge for transition progress towards sustainable energy system. The dynamic hypothesis has to lead to identification of these stocks and parameters, as well as flows, which relate the parameters to the stocks. For the dynamic hypothesis, we took a holistic approach considering the pace of co-evolution of the knowledge-technology landscape, the socio-economic landscape and the socio-cultural landscape and their mutual interactions. Instead of assuming that the energy sector at any given moment of time is formed under conditions of technical-economic optimization, the constraints imposed by differing of rates of development of critical parts of the socio-technical system are considered. These constraints could deviate a system from the optimal conditions.

The most important factor of measurement of the decarbonisation progress is the annual carbon emissions related to energy services (Fig. 1 ), and this measurement could be the main stock of a model. The value of this stock depends mainly on two factors - annual demand for energy services and carbon-intensity of energy services. Annual demand for energy services, in turn, depends mainly on the willingness to purchase energy services (if these are available-supplied by a market), the number of people, and climatic conditions (this factor is not included in the Fig. 1 but there is a link between carbon emissions and long-term climatic conditions). Willingness to purchase energy services is affected by several factors, with values and economic considerations probably being the most important. Environmental pressures, i.e. climate change caused by $\mathrm{CO}_{2}$ emissions, influence both values and economic considerations since these pressures have an effect on the direct costs associated with energy services. There is a very important feedback from annual $\mathrm{CO}_{2}$ emissions to environmental pressures, and the policy regime most likely imposes additional costs on the supply of energy services. A feedback from the adoption rate of new technologies to direct costs of supply may lead to decreasing costs of supply due to learning effects, thus increasing the willingness to purchase energy services, ceteris paribus. 
The carbon-intensity of energy services, in turn, depends mainly on new technology development and adoption rates. Policies may stimulate the technology development rate by supporting research and development and creating certain legislation and regulatory frameworks. Increase of the adoption rate of new technologies also may result in an increasing rate of technological development. The adoption rate of new technologies depends mainly on investment decisions in supply and demand sides and market change, i.e. the emergence of new business models favouring these new technologies. Policies may also support investment decisions by providing support, both financial and legal/regulatory (e.g. removing barriers), for entrance of these new technologies in the market. Market change may also have an impact on investment decisions in new technologies. [20] shows how policy support for biomethane production and supply can be modelled with a SDM, by creating co-flows representing permits granted for electricity sales with feed-in premiums and physical capacity building for biomethane production. Fig. 1 reflects relations of conditions, drivers and outcomes when focus is on the environmental drivers and does not include such drivers as energy security and economy.

Since it is impossible to describe in detail all elements and relations shown in Fig. 1, this paper focuses on the adoption rate of new technologies for illustrating how SDM can be applied for quantitative modelling of sustainable energy transitions. The illustration is done in Section 5 on the conceptual level with the help of causal loop diagrams. It is based on the concepts obtained from the analysis of the sustainable transition literature summarised in Section 4.

\section{Concepts from the sustainable transitions literature for improved modelling of energy transitions pathways}

Next, we discuss concepts from the sustainable transition (ST) literature that may be used to identify and analyse mechanisms or variables affecting energy transition pathways. We first introduce the concept of transitions pathways and its variants, highlighting how technological development unfolds in often non-linear ways. Drawing on the strategic niche management approach, we then discuss technological niches and the conditions for their development, as niche development is central in energy transitions. Next, we consider the role of expectations and visions in technological development, which have received much attention by ST scholars. A fourth concept central to modelling energy transitions pathways is path dependence and in this context we discuss a number of lock-in mechanisms that can reinforce a certain development pathway in energy systems. The last set of concepts that cut across the previous ones mentioned are institutions and actors; we focus this discussion on how political processes and corporate strategies may influence transitions pathways.

\subsection{Transitions pathways}

The notion of transitions pathways has been defined as "patterns of changes in socio-technical systems unfolding over time that lead to new ways of achieving specific societal functions. Transitions pathways involve varying degrees of reconfiguration across technologies, supporting infrastructures, business models and production systems, as well as the preferences and behaviour of consumers" [12]. This concept could be used to analyse e.g. alternative patterns of change of the Nordic energy system.

[21] first introduced the concept and developed a typology, which distinguishes between four pathways: the transformation pathway, the reconfiguration pathway, the technological substitution pathway, and the de-alignment and re-alignment pathway. Below we discuss this typology, starting out with the initial descriptions by [21] and then discuss the further points made in [2].
The transformation pathway involves mainly regime actors and some groups outside the regime (social movements), which voice criticism. The regime actors just adjust the regime rules, such as goals, heuristics, and guiding principles. Here [2] point out that incumbents and not just new entrants may also reorient towards radical technological innovations. The reorientation happens not just towards incremental innovations for existing technologies, but also by adding competences and by reorientation towards new technologies.

The reconfiguration pathway involves both regime actors and suppliers, which develop novel solutions, and the regime actors incorporate these solutions. This leads to adjustments in the basic architecture of the regime. [2] observed that this pathway also involves new alliances between incumbents and new entrants, and that niche innovation are initially incorporated as modular innovations or add-ons to existing technologies. Later these new technologies may lead to unintended effects and second-order learning effects, and both could trigger cascades of innovations.

The technological substitution pathway involves a competition between incumbent firms and new firms with new technological solutions. If there is enough pressure, the new niche firms will break through and replace the existing regime. [2] stressed that not just new firms and established firms struggle with each other, but that also outsiders and incumbents from other sectors may enter the struggle for a new pathway.

The de-alignment and re-alignment pathway involves new niche actors. A multitude of novelty emerges, and new entrants compete for resources, attention and legitimacy. Eventually one novelty will win and the regime will re-stabilise. [2] argues that this pathway is based on external large shocks, such as those caused by wars, 'cold war' periods when mutual trust in international relations are challenged, economic crises, or ecological disasters such as Fukushima.

[2] concluded that there is no linear development from one pathway to another. Instead, the shifts between the different pathways depend more on endogenous factors than on external landscape impact. Active delays, power struggles and counter-movements can cause non-linear developments.

[22] highlight that low-carbon transitions cannot easily be modelled as a process of steady increasing deployment of low-carbon technologies. The dynamics of such transition processes have to be taken into account, involving analysis of: (a) a wider spectre of actors with their competing interests, beliefs and practices, (b) the non-linear changes of user practices, discourses and political struggles around these transitions, (c) the alignment between long-term benefits of low-carbon developments and other objectives of relevant stakeholders, and (d) the directionality of public policy towards low-carbon transitions (ibid.).

\subsection{Strategic niche management}

The strategic niche management (SNM) approach has been developed to address niche processes and to some degree to provide policymakers a tool for supporting niche development [23]. [24] define SNM as "the creation, development and controlled phase-out of protected spaces for the development and use of promising technologies by means of experimentation, with the aim of (1) learning about the desirability of the new technology and (2) enhancing the further development and the rate of application of the new technology."

[25] emphasises that there is no linearity in technological development. This has been confirmed for Dutch biogas development [26] and by a study of biomass technologies in Denmark and The Netherlands, which found no linear pattern in the observed development of technological niches towards protected market niches and dedicated market niches and eventually regime shifts [27]. Finally, [28] observed that 
the varying local context conditions play a major explanatory role in niche development.

Instability at the regime level increases opportunities for niche development, which can result in increased niche size. [29] distinguishes between three possible avenues: (1) regime instability can create local opportunities for experiments and niche actors develop expectations linked to regime instability; (2) with a decreasing stability of the regime the regime actors become interested in the niche because of promising options for the future; and (3) in the case of very high instability of the regime a niche can be adopted by the regime as a problem solver, but for this a sense of urgency has to become prominent in political visions and agreements [29].

The quality of the niche processes is also decisive for niches to succeed and the following have been highlighted as decisive for successful niche development: facilitating learning processes, the formation of broad and aligned networks and institutional embedding, voicing and shaping of expectations and visions, the development of complementary technologies and infrastructures, supporting technology diffusion (up-scaling) [29-31].

\subsection{Expectations and visions}

[32] investigates the role of promises and expectations in technological development - how promises about technologies are converted into design specifications. Expectations and visions are constituent for technological development [33]. However, expectation statements only contribute to the development of technology niches if they become a part of agenda building processes [34]. Agenda building processes and expectations influence each other. Expectations get converted into requirements and task divisions at different levels. At the micro level, specific ideas about promising search routes guide solving of specific problems; at the meso level visions and expectations about functionality result in functional requirements; at the macro level the cultural level of expectations justifies technological development for achieving sustainable development [29].

Expectations change over time, alternating between hypes and disappointment [35]. When early technological expectations downplay organisational and societal factors, the dis-appointments are inevitable. Shifts in expectations have triggered actors to search in different application domains, contributing to niche branching. However, shifts in niche expectations are mainly caused by external changes, e.g. policies, and only to some degree by internal learning processes $[29,36]$. Raven concludes that "a broad set of expectations is important in the beginning of a niche trajectory (to allow a parallel and continuous pattern), but expectations should be made concrete and tested in experiments along the innovation journey ..." [29]. Regarding the effect of learning outcomes, then [36] observed that when learning outcomes validate and accept the initial expectations a new development cycle is initiated that enables further incremental refinement, but if learning outcomes are below the initial expectations "faith in the new technology diminishes and expectations decline" [36]. Eventually, new expectations will be developed and non-linearity occurs if they come on the agenda.

\subsection{Path dependence and lock-ins}

Path dependence is the tendency of institutions or technologies to become committed to develop in certain ways because of their structural properties or their beliefs and values [37]. Path dependence is important for understanding and modelling energy transitions pathways as it suggests the existence of mechanisms that (under certain conditions) can cause some technologies, behaviours or policies to persist or dominate even if "superior" alternatives exist. While such lock in mechanisms cause considerable inertia in energy systems, a change in path- dependent systems is still possible through feedback mechanisms, as also highlighted by the SNM approach.

[38] have developed an analytical framework studying systematically the role of lock-in mechanisms in transition processes. They understand lock-in mechanisms as "mechanisms, which reinforce a certain pathway of economic, technological, industrial and institutional development and can lead to path dependence". [38] observed that there can be interactions between lock-in mechanisms, such as between learning effects, network externalities and technological interrelatedness, which are reinforcing each other, or between symbiotic relationships and institutional learning effects, where the former is weakening the latter. Below we discuss a selection of the mechanisms discussed by [38], which we find especially relevant for this review.

\subsubsection{Learning effects and learning processes}

Learning effects influence transition pathways through their effects on the cost and performance of alternative energy technologies and through institutional learning in relation to e.g. better policies, collaborations, ownership models, servicing etc.

Institutional learning effects are the outcome of the increased adoption of institutions, which makes them rather complex and difficult to change, even when mistakes have been clearly identified, while at the same time providing improved coordination and adaptive expectations [39].

Increasing returns lead to learning effects, according to [40]. They facilitate the development of higher quality products and the improvement of processes by incremental innovation. Learning effects occur when knowledge, skills and organisation routines increase with cumulative production.

Increased adoption may also lead to learning-by-using, providing important feedback about the needs of users for incremental product development. The learning effects lead to lower costs, which eventually can be measured by learning curves [41]. This sequence of historical events points to the role of national scientific and technological specialisation $[42,43]$.

Practical experience, [23] argue, is necessary to generate knowledge required to accommodate introduction of new technologies. Because such knowledge cannot be acquired in house, there is a need for an experimental introduction of novel technologies into use environments [23]. Technological niches are often created through experiments, and pilot and demonstration projects [23].

Learning through demonstration projects has been addressed recently [44-47]. Demonstration projects address not only pure technical challenges, but also help reducing the organisational, market, and institutional risks and uncertainties [48]. They require a policy mix to become successful [49].

First and second order learning is an important distinction. "First-order learning refers to learning about the effectiveness of a certain technology to achieve a specific goal. First-order learning aims to verify pre-defined goals, to reach goals within a given set of norms and rules. Second-order learning refers to learning about underlying norms and assumptions and is about questioning these norms or changing the rules" $[29,30]$ including conceptions about technology, user demands, and regulations.

Learning in niches. Learning enables stabilisation at the niche level and is therefore the most crucial process for emergence of a market niche. Beside learning inside an experiment, learning between different locations and between different social groups is a prerequisite for the success of the niche [29]. [23] highlight the following aspects of learning as relevant for niches: (1) design specifications of technical development and infrastructure; (2) development of the user context, including user characteristics, their demands and their barriers to use the new technology; (3) the societal, safety and environmental impact of the new technology; (4) required industrial development, including 
production and maintenance networks to facilitate diffusion of the new technology; and (5) government role and regulatory framework in the introduction process, and possible incentives to stimulate adoption [23].

\subsubsection{Increasing returns to scale and scope}

Economies of scale emerge when sunk costs from earlier investments in production capacity are spread over an increasing production volume in the socio-technical system. Economies of scale can be explained by increasing returns as fixed costs are spread over more units of production output and by the functions of the built-up infrastructure, especially for larger technical systems such as energy production or transportation [50]. Infrastructure such as electricity generation or transport systems becomes more efficient and gains momentum when more users plug into the system. Yet, the inertia of this infrastructure locks the system into a chosen direction. However, [51], page 117, also point out that not all technologies achieve increasing returns through scale economies, e.g. hydroelectric power becomes more costly as dam sites become scarcer and less suitable.

The widespread use of a technology may allow for economies of scope, i.e. cost advantages induced by the production and use of a variety of products rather than specialising in the production of one type of product. [52] emphasise the potential of achieving cost efficiency because of economies of scope. This is connected to product diversification in different niche markets.

Informational increasing returns occur because the adoption of a technology means that it receives greater attention, which in turn stimulates other users to adopt it [53]. Examples of such cases include rooftop PV systems, home automation, or electric vehicles.

\subsubsection{Network externalities}

Network externalities emerge because of early de facto standard setting in industrial networks, which require compatibility and because many consumers purchase compatible products [54]. This mechanism is especially important for infrastructure development in ICT, energy or transport, but also for the adoption of technology by end consumers such as mobile phones, computer software and electric vehicles.

\subsubsection{Technological interrelatedness and infrastructures}

Technological interrelatedness occurs because the adoption of a technology favours the development of complementary technologies, decreases technological uncertainty, while potential users may adapt their expectations regarding quality, endurance and the performance of the technology. A case in point is that the adoption of VRE technologies stimulates the demand for technologies that raise energy system flexibility. Technologies that are incompatible with the dominant technological regime are locked out, however [53]. In this context, [23] observe that the development of technological niches depends on the introduction of complementary technologies and infrastructures. Existing infrastructures are not adapted to the needs of the new technology, and complementary technologies - such as automated demand response, ICT for smart grids, or big data analysis - often have to be developed or at least to be adapted to the needs of the new technology. Regarding infrastructure, such as EV charging stations, new distribution systems have to be established and maintenance requirements have to be introduced and the work force to be introduced for the new technology [23]. Investments in the old infrastructure constitute a strong lobby for own, and probably diverging, interests. The value of the new infrastructure and maintenance investments is often rather high and requires therefore decisions and collaboration on cost defraying. This issue is especially important when large technological systems are to be changed, as is the case for energy infrastructure [55]. In gen- eral, policy has mainly focussed on enabling renewable electricity generation, while complementary innovations like energy storage, demand response, energy efficiency, transmission and distribution grid, and new business models and market arrangements to ensure energy system flexibility and security have received much less policy support.

\subsection{Institutions and actors}

Actors and institutions can influence energy transition pathways in profound ways, in particular through political processes at local, national and international levels, but also through the strategies and behaviours of companies and consumers. In a modelling context, [11] argue for distinguishing between social processes that emerge from the uncoordinated actions of many actors (e.g. increasing returns to scale, diffusion of innovations) and those caused by the coordinated actions or discussions of a few actors. The former type is partly covered by the above discussions on expectations, learning and path dependence but covers also the important aspect of consumer behaviour. The latter process includes political processes and the strategic actions of core industry actors (e.g. wind turbine producers and large utilities) and are 'contingent on potentially very specific circumstances of the actors involved and the institutional setting' [11]. This specificity and contextuality make such processes difficult to model and generalise, while ignoring them could mean excluding central dynamics and interactions from the analysis.

In terms of political processes, then the political perspective is generally weakly represented in the sustainable transitions literature [13], limiting the ability to explain changes in policies that affect the energy system. In this regard, [13] argue that the political system is a semi-autonomous system with its own dynamics that co-evolve with socio-technical and techno-economic systems. To strengthen the understanding of the political system in analyses of energy transitions, they and e.g. [56] propose to draw on political science and related literature, including the use of the concepts of state and state policies, institutions, institutional capacities, policy paradigms, varieties of capitalism (liberal vs. coordinated), and policy convergence and diffusion across nation states. In terms of the modelling of energy transition pathways, then such analyses could improve model specifications, e.g. through feed-back loops, in terms of how national energy policies are dynamically linked to environmental pressures, societal values, social acceptance of energy technologies, state regulatory capacities, ownership of production equipment (e.g. prosumers vs. large corporations) and larger-scale policy process (e.g. EU).

The strategic actions of industry actors have been extensively analysed by transitions scholars, in relation to investments in energy technologies and infrastructures, horizontal integration of energy companies (often through mergers and acquisitions, such as in Germany and the United Kingdom [2]), vertical integration through foreign direct investment [57], and the creation and use of transnational linkages to access knowledge, technologies, capital etc. [58]. Energy transition studies have also highlighted industry's 'political work' in relation to both regime and niche processes [59]. This literature documents how industries strategize and act in response to changes in markets and regulations (e.g., [60], but also that firms can yield considerable influence on policies as well as change market conditions. For energy modelling, deep knowledge of industry strategic actions thus seems important to specify the interactions between policy and rates of technology development and deployment, but also feedback loops from such investments and policy support. Industry actors may also be central to the development of technologies that cause disruptive system changes, such as the plummeting cost of photovoltaic and wind energy in recent years. 


\section{Application of system dynamics to modelling of energy transitions}

Based on the analysis of concepts from the sustainable transition literature in Section 4, a transition process can be characterized by nonlinear shifts from one pathway to another. These shifts depend mostly on endogenous factors rather than external impacts. Therefore, when making a quantitative model for sustainable energy transition analysis, one needs a tool that allows encountering main reinforcing and balancing effects, which are created by the system's structure itself, and dynamics of shifting of dominance between these effects over time. The limitation of most so-called traditional modelling tools lies in the inability to capture these complex dynamics, which result from the internal structure of the system under analysis. Furthermore, as shown in this section, the modelling approach must enable quantitative description of transition not only in the technology domain, but also in the institutional, market, and social domains. We propose SDM as an approach, which may help filling this gap. This section describes how system dynamics differs from other modelling approaches, its strengths and limitations, and demonstrates how causal loop diagrams (CLDs) may represent the concepts described in Section 4. CLDs serve as a dynamic hypothesis about a structure of the studied system, which is responsible for exhibited dynamic behaviour (e.g. behaviour that slows down the transition process). CLDs are used as input for the construction of the quantitative model, i.e. turned into stock-and-flow models that can be quantitatively modelled.

\subsection{How system dynamics models differ from traditional models}

System dynamics models have been successfully used for energy system modelling for decades and a good overview is provided in [61]. The main advantage of system dynamics over traditional modelling approaches using econometric and linear programming methods is its ability to capture the complex and dynamic nature of energy systems. Namely, with system dynamics models we are able to consider:

1. Information feedback loops affecting demand and investment decisions, regulations and policy implications, environmental awareness of society;

2. Material (e.g. power generation capacity construction) and information (e.g. price signals, level of knowledge about new technologies) delays;

3. Co-development (co-flows) and mutual interaction of material (e.g. capacities of various technologies) and non-material (e.g. level of expertise, technology-readiness levels) stocks;

4. Non-linear causal relations governed by reinforcing and balancing forces (e.g. diffusion of new technologies and limits to growth) which are characteristic for technology disruptions in socio-technical systems.

The most fundamental difference of system dynamics modelling compared with many traditional modelling tools is its endogenous approach - understanding and modelling of the structure of a system, which is responsible for its dynamic behaviour. This modelling approach allows us to consider that the impact of socio-technical factors and decisions is exhibited via information feedback loops that constantly change the system under study. The ability to simulate the information feedback in the system is what makes system dynamics approach so unique [62].

Many integrated energy-economy-climate models use economic optimization and equilibrium assumptions [63]. System dynamics models of energy-economy interactions, however, study disequilibrium dynamics, by including behavioural decision rules and explicitly modelling stocks and flows of capital, labour, resources and money. A more realistic representation of energy transition requires consideration of a disequilibrium energy-economy-social system with delays in perception and adjustment, endogenous technological change, feedback effects and explicit behavioural rules, rather than optimization while assuming complete information and instantaneous equilibration of factor inputs to optimal levels.

Quantitative energy models often have a limited focus on techno-economic factors, but political, social, and behavioural aspects are framed exogenously [64]. Socio-technical transition models (STET) in which quantitative modelling of energy system transitions includes also co-development of technology, economic, policy and behavioural factors have therefore been proposed [64]. These models have three main requirements. First, there should be a sufficient techno-economic detail with disaggregated technology options having certain cost and performance characteristics, and operational or resource constraints. Second, these models have to consider multiple explicit actors with differentiated behavioural parameters and ability to influence transitions. Third, the models should be able to capture transition pathway dynamics providing sufficiently long-time horizons (as opposed to snapshots of conditions at certain future time periods), as well as include assessment of normative goals and radical alternatives to the existing technologies or behaviour models which allow actors to break out from the locked-in systems. Several models which were identified as STET models [64] have actually used a system dynamics approach. These models may be able to capture socio-technical transitions as successfully as agent-based models, which represent almost half of all reviewed STET models. One area for future improvement of STET models is the representation of co-evolutionary factors of social interaction. System dynamics models include endogenous social mechanisms, in which actors are able to influence each other's decisions [64]. It is also noted by [64] that it may be too challenging to create an ideal STET model which corresponds to all the three major requirements. An option could be linking of several models, with each providing sufficient details within their core elements.

In distinction to optimization models (e.g. MARKAL/TIMES, MESSAGE and DIME), system dynamics models are flexible and allow integration of strategic behaviour and absence of complete information, thus reflecting market imperfections and failures [65]. Neglect of market failures and adjustment delays is characteristic also to computable general equilibrium (CGE), and partial equilibrium models, which do not consider interrelations [65], as opposed to system dynamics models. Agent-based models, which belong to the same category of simulation models as system dynamics, have a drawback of requiring enormous amounts of empirical data for the simulation of behaviour of individual agents [65].

Energy modelling currently tries to combine strengths of so-called top-down models (input-output models, econometric models, computable general equilibrium models and system dynamics), which provide endogenous assessment of economic and societal effects, with bottom-up models (partial equilibrium models, optimization models, simulation models, multi-agent models), which are able to provide higher technological detail [66]. Both modelling approaches are combined in so-called hybrid energy system models by either soft linking, i.e. manual transfer of data, parameters and coefficients, or hard linking by using automatic routines [66]. Thus, combining system dynamics with technologically detailed optimization models could be a prospective direction for modelling of socio-technical energy transitions. The challenge lies in keeping those models theoretically consistent and empirically valid, while avoiding huge incomputable models [66]. 


\subsection{Reinforcing and balancing processes in energy transitions}

The shifting of power between reinforcing (R) and balancing (B) loops can be illustrated with a conceptual figure representing the possible character of dynamics of the share of electricity produced by variable renewable energy source (RES) technologies (Fig. 2). Niche innovations and technology (and business model) disruptions are diffusing at increasing rate initially, as technology becomes more competitive and society more adaptive to these innovations with increasing market share [22]. However, the rate of diffusion starts to decline as soon as we approach the limits of the existing market conditions $[67,68]$. These limits could be imposed by flexibility restrictions of the existing power system [69], land, and infrastructure availability for construction of new capacity, limited pool of adopters of new technologies, etc. [70].

When approaching these limits, the pressure to innovate and breaking these limits may become stronger, but simultaneously will need political support and institutional changes [68].

Reinforcing loops R1 and R2 portray learning effects of actors involved in the energy transition (Fig. 3), leading to increased willingness to invest in wind power (WPP) and residential solar PV as more capacity is installed. A larger installed capacity of WPP results in increased rate of WPP technology development and decreased land required per unit of capacity of WPP, which leads to less of the total land required for WPP, ceteris paribus. It results in more remaining land available for construction of WPP (constrained by the total land available for that purpose), stimulating investment decisions in new WPP capacities [71]. Increased willingness to invest in WPP leads to even larger WPP capacity in the next turn. Increased capacity of residential solar PVs leads to increased rate of solar PV technology development, which causes unit costs of PV production to decline. The decreased unit costs of solar PV lead to increased willingness to invest in residential PV, increasing the capacity of PV and leading to even faster rate of technology development [72]. Modelling can encounter also other effects, which may strengthen reinforcing loops, i.e. information increasing returns ("word-of-mouth effect"), network externalities, collective action, economies of scale, and institutional learning effects.

Even though technological development of WPP reduces the land required per unit of capacity, construction of new WPP will inevitably lead to increase of the total land required for WPP and will exhaust remaining land available for WPP (Fig. 3) [73]. As the land for WPP construction becomes scarce, less investors will be willing to invest in WPP capacity and less capacity will be constructed. Thus, a balancing loop B1 is formed, imposing limits to growth to the reinforcing loop R1, and this balancing loop gains strength as the limit of the available land is approached. For residential solar PV, diminishing number of potential adopters of PV may impose the limits to growth, forming the balancing loop B2. Flexibility limits of a power system may be a limiting factor for both technologies and form additional balancing loops.

Potential interaction between residential solar PV and WPP may be characterized by the balancing loop B3, limiting the growth of WPP. Increased capacity of WPP may require more investments in the power grid to absorb more of the variable power and preserve stable operation of a grid [74]. Increased investments in the grid lead to increased grid connection fee, thus creating incentive to invest more in residential solar PVs, ceteris paribus. ${ }^{1}$ As more capacity of residential solar

1 This is if a rate structure of transmission and distribution services or co-development of storage technologies create incentive for that; a potential decrease in power spot-market price as the share of WPP produced electricity increases could make grid power more attractive.
PV's is installed, less of electricity is demanded from a grid; thus, less power produced by WPP is purchased by residential customers. Diminishing demand for grid-supplied power decreases the willingness to invest in WPP capacity.

One of the niche innovations with high potential in the future is de-centralized power production, which could partially replace the existing system, based on centralized large-scale power plants. De-centralized clean energy production systems are highly relevant to the energy transition.

In case the power costs provided by large scale power plants exceed a threshold and continue to rise, power consumers start to search for options to decrease the costs of energy (Fig. 4). Balancing loops B1 to B3 illustrate possible behaviour of the consumers. Before examining options, which require financial investments, consumers most likely will try to change their regular behaviour to decrease the costs of electricity. The first step would be a change in behaviour by using less power - switching off electric appliances when not needed, turning off lights when leaving the room, etc. (B1) [75]. If it is not enough and power costs are still increasing, consumers might transfer their peak consumption to off-peak hours, when electricity price is lower (B2), which would increase energy system flexibility [76]. If many consumers decide to transfer power consumption to off-peak hours, the power load becomes more balanced with less significant peaks, which results in lower demand for peak capacity of power plants. With lower capacity, but more balanced power production, power production costs might increase due to economies of scale (lower capacity results in higher investment per capacity unit), but the costs might as well decrease due to more efficient utilization of installed capacities (R6).

In case the change in behaviour is not sufficient, or if consumers become more aware of the environmental pressure that the current power sector is inflicting, they might consider becoming prosumers and produce energy by themselves e.g. by installing solar PV panels on their roofs (B3) [77].

Reinforcing loop R1 illustrates the learning effect. When more consumers become prosumers, more information about this practice is accumulated, more people are informed, which in turn helps to make the concept more attractive to others.

Reinforcing loops 2-4 illustrate the effect that the development of de-centralized power production has on large-scale power production and costs. We can assume that there are current large-scale power production technologies and that there will be large-scale niche innovation technologies, which both compete with de-centralized power production. If power costs, provided by large-scale power plants are too high for consumers, they may gradually switch to a de-centralized system and produce most of the power themselves. This in turn decreases the amount of power produced by large-scale power plants (both current and niche technologies), which results in reduction of power plant capacities [78]. As for most of the technologies economies of scale apply, reduction in capacities eventually means that costs of power production in large-scale power plants increase, therefore promoting de-centralized power production even further (R3 and R4). Large-scale incumbent technologies compete not only against a de-centralized system, but also against each other, and technologies with most benefits under existing rules and institutions are developed (R5). Development of de-centralized system not only transforms the production part, but also reconfigures transmission and distribution of power [78]. De-centralized system with a lot of prosumers located nearby promotes the development of micro-grids, when power is distributed between local consumers and only excess power is transmitted to the grid. This helps to reduce transmission losses and costs for micro-grid users, but increases average fixed transmission costs for other consumers, therefore increasing power costs from the grid even more (R2) [79]. 


\subsection{Applying the methodology to the case of energy system flexibility}

A transition to sustainable energy systems inherently calls for more careful matching of power demand and supply, as utilizing variable renewable energy sources (RES) will increase supply variations [80]. Therefore, flexibility is chosen here as a case for SDM. Flexibility of the energy system will be one of the important factors affecting the adoption rate of RES technologies (Fig. 5).

As technical constraints of flexibility become more pressing, i.e. the share of variable power production approaches the maximum limit of an energy system (further increase of capacity may lead to instabilities or loss of production), the adoption rate of RES technologies decreases, ceteris paribus [80]. The decrease of adoption rate leads to higher carbon-intensity of energy services, increasing the environmental concern, which, results in increased public awareness of the environmental problems (climate change). Increased public awareness results in increased policy support for RES, which may be exhibited in the form of increased support for research and development (R\&D) [81]. Increased investment in R\&D brings a higher rate of technological development of flexibility solutions, which will relax technical constraints of flexibility. Thus, a balancing loop B1 is formed and the loop helps to stabilise carbon-intensity of energy services [80,81]. Another balancing effect (loop B2) may be created by increased formation of new business possibilities (market change) as technological development rate of flexibility solutions increase (new businesses are driven by arrival of new technologies). New business possibilities will stimulate investment decisions in new technologies, thus an increasing adoption rate of RES technologies $[78,82,83]$.

In the description of the strategic niche management in Section 4, it was noted that a decreasing stability of existing regime may lead to seeking solutions, which will solve the problem and may provide opportunities for a niche and disruptive technologies. As technical constraints to flexibility become more urgent, the stability of the existing regime, e.g. power system, declines, which in turn increases the motivation to develop new flexibility solutions. This motivation may be exhibited in increased support for R\&D leading to increased rate of development of flexibility solutions, relaxed flexibility constraints and increased adoption rate of new technologies, and a balancing loop B3 is formed $[78,82]$. Increased deployment of flexibility solutions furthermore depends on changes in energy regulation such as tax reforms that incentivize flexible energy consumption and stronger coupling of energy markets (not shown in Fig. 5). Effects of technological disruption removing barriers for power production from intermittent RES technologies have been demonstrated quantitatively by using a conceptual system dynamics model [84]. The stock-and-flow model demonstrates the effect of a positive feedback decreasing unit costs of RES power production as a result of learning effects. It also demonstrates a balancing feedback leading to a decreasing rate of RES capacity installation as the flexibility limit for intermittent power integration into energy supply system is approached. The study shows that a stepwise increase of the limit for intermittent power integration resulting from technological development leads to an S-shaped increase of RES power production, as expected from a structure governed by the interaction of reinforcing and balancing effects described above.

\subsection{Integration of sustainability transitions concepts in system dynamics modelling}

Table 2 below summarises how the concepts from the sustainability transitions (ST) literature would be approached and integrated in system dynamics modelling of energy systems. It also recapitulates the relevance of the concepts for analysis of energy system flexibility in general. Note that the table lists more concepts than were applied in the il- lustrative loop diagrams above in an attempt to provide a framework with generic value.

\section{Conclusions}

Here we have reviewed different methodological approaches used for energy transition modelling. We also discussed how a SDM approach could be employed for improved modelling of such transitions. We applied these approaches for incorporating energy system flexibility into the energy transition context.

Analysis of concepts from the sustainable transitions literature shows that a transition process can be characterized by nonlinear shifts from one pathway to another, depending on endogenous factors rather than external impacts. Therefore, a quantitative model for sustainable energy transition analysis has to encounter the main reinforcing and balancing effects, which are created by the system's structure itself, and dynamics of shifting of dominance between these effects over time. The main strength of SDM when compared with several other traditional modelling tools is its endogenous approach, in particular understanding and modelling the structure of a system, which is responsible for the dynamic behaviour. In SDM, the impact of socio-technical factors is exhibited via information feedback loops that constantly change the system balance under consideration. Furthermore, the modelling approach must enable quantitative description of transition not only in the technology domain, but also in the market, institutional, and social domains. Concepts from the sustainable transitions literature can help identify important mechanisms and variables within these domains. Many of these concepts are furthermore relevant to the analysis of flexibility in energy systems. SDM can capture the co-evolution of technology, economy, policy and behavioural factors over sufficiently long-time periods, which is necessary for the analysis of transition pathway dynamics. From a computational point of view, it could be beneficial to combine SDM with technologically detailed energy-system optimization models, and that could be a way forward for achieving more realistic, non-linear quantitative modelling of sustainable energy transitions. Such an approach could also be attractive for studying complex energy transitions, which involve energy system issues related to flexibility.

\section{Acknowledgements}

This work as supported by the Nordic Energy Research [grant number 76084]; and the Research Council at the Academy of Finland [grant numbers 312623 and 285353]. The opinions expressed here do not necessarily state or reflect those of the Nordic Energy Research, the Nordic Council of Ministers, or the Research Council at the Academy of Finland. The authors are solely responsible for the contents of the paper.

\section{References}

[1] IPCC, Climate change 2014: mitigation of climate change, Cambridge University Press, Cambridge, 2014https://doi.org/10.1017/CBO9781107415416.

[2] F.W. Geels, F. Kern, G. Fuchs, N. Hinderer, G. Kungl, J. Mylan, et al., The enactment of socio-technical transition pathways: a reformulated typology and a comparative multi-level analysis of the German and UK low-carbon electricity transitions (1990-2014), Res Policy 45 (2016) 896-913, https://doi.org/10.1016/j. respol.2016.01.015

[3] F.W. Geels, F. Berkhout, D.P. Van Vuuren, Bridging analytical approaches for low-carbon transitions, Nat Clim Chang 6 (2016) 576-583, https://doi.org/10. 1038/nclimate2980.

[4] B.K. Sovacool, How long will it take? Conceptualizing the temporal dynamics of energy transitions, Energy Res Soc Sci 13 (2016) 202-215, https://doi.org/10. 1016/j.erss.2015.12.020.

[5] A. Grubler, C. Wilson, G. Nemet, Apples, oranges, and consistent comparisons of the temporal dynamics of energy transitions, Chem Phys Lett 22 (2016) 18-25, https://doi.org/10.1016/j.erss.2016.08.015.

[6] D.P. van Vuuren, M. Kok, P.L. Lucas, A.G. Prins, R. Alkemade, M. van den Berg, et al., Pathways to achieve a set of ambitious global sustainability objectives by 2050 : 
explorations using the IMAGE integrated assessment model, Technol Forecast Soc Change 98 (2015) 303-323, https://doi.org/10.1016/j.techfore.2015.03.005.

[7] C.S.E. Bale, L. Varga, T.J. Foxon, Energy and complexity: new ways forward, Appl Energy 138 (2015) 150-159, https://doi.org/10.1016/j.apenergy.2014.10.057.

[8] P. Ringler, D. Keles, W. Fichtner, Agent-based modelling and simulation of smart electricity grids and markets - a literature review, Renew Sustain Energy Rev 57 (2016) 205-215, https://doi.org/10.1016/j.rser.2015.12.169.

[9] K.B. Karlsson, M. Münster, K. Skytte, C.H.C. Pérez, V. Giada, R. Salvucci, et al., Nord Energy Technol Perspect 2016 (2016) https://doi.org/10.1787/ 9789264257665-en.

[10] J.G. Kirkerud, E. Trømborg, T.F. Bolkesjø, Å.G. Tveten, Modeling the power market impacts of different scenarios for the long term development of the heat sector, Energy Procedia (2014) https://doi.org/10.1016/j.egypro.2014.10.421.

[11] G. Holtz, F. Alkemade, F. De Haan, J. Köhler, E. Trutnevyte, T. Luthe, et al., Prospects of modelling societal transitions: position paper of an emerging community, Environ Innov Soc Transit 17 (2015) 41-58, https://doi.org/10.1016/j.eist. 2015.05.006.

[12] B. Turnheim, F. Berkhout, F. Geels, A. Hof, A. McMeekin, B. Nykvist, et al., Evaluating sustainability transitions pathways: bridging analytical approaches to addres governance challenges, Glob Environ Chang 35 (2015) 239-253, https://doi.org/ 10.1016/j.gloenvcha.2015.08.010.

[13] A. Cherp, V. Vinichenko, J. Jewell, E. Brutschin, B. Sovacool, Integrating techno-economic, socio-technical and political perspectives on national energy transitions: a meta-theoretical framework, Energy Res Soc Sci 37 (2018) 175-190, https://doi.org/10.1016/j.erss.2017.09.015.

[14] The International Energy Agency. World Energy Outlook 2017. Int Energy Agency; 2017. 〈http://dx.doi.org/10.1016/0301-4215(73)90024-4〉.

[15] O. Koskinen, C. Breyer, Energy storage in global and transcontinental energy scenarios: a critical review, Energy Procedia 99 (2016) 53-63, https://doi.org/10. 1016/j.egypro.2016.10.097.

[16] Child M, Koskinen O, Linnanen L, Breyer C. Sustainability guardrails for energy scenarios of the global energy transition; 2018. 〈http://dx.doi.org/10.1016/j.rser. 2018.03.079>.

[17] A. Blumberga, G. Bazbauers, P.I. Davidsen, D. Blumberga, A. Gravelsins, T. Prodanuks, System dynamics model of a biotechonomy, J Clean Prod 172 (2018) 4018-4032, https://doi.org/10.1016/j.jclepro.2017.03.132.

[18] B. Turnheim, F. Berkhout, F. Geels, A. Hof, A. McMeekin, B. Nykvist, et al., Evaluating sustainability transitions pathways: bridging analytical approaches to addres governance challenges, Glob Environ Chang 35 (2015) 239-253, https://doi.org/ 10.1016/j.gloenvcha.2015.08.010.

[19] P.D. Lund, J. Lindgren, J. Mikkola, J. Salpakari, Review of energy system flexibility measures to enable high levels of variable renewable electricity, Renew Sustain Energy Rev 45 (2015) 785-807, https://doi.org/10.1016/j.rser.2015.01.057.

[20] M. Repele, L. Udrene, G. Bazbauers, Support mechanisms for biomethane production and supply, Energy Procedia 113 (2017) 304-310, https://doi.org/10.1016/j egypro.2017.04.070.

[21] F.W. Geels, J. Schot, Typology of sociotechnical transition pathways, Res Policy 36 (2007) 399-417, https://doi.org/10.1016/j.respol.2007.01.003.

[22] F.W. Geels, B.K. Sovacool, T. Schwanen, S. Sorrell, The socio-technical dynamics of low-carbon transitions, Joule 1 (2017) 463-479, https://doi.org/10.1016/j.joule. 2017.09.018.

[23] R. Hoogma, R. Kemp, J. Schot, B. Truffer, Experimenting for sustainable transport: the approach of strategic niche management 1st ed., Routledge, London, 2002.

[24] R. Kemp, J. Schot, R. Hoogma, Regime shifts to sustainability through processes of niche formation: the approach of strategic niche management, Technol Anal Strateg Manag 10 (1998) 175-198, https://doi.org/10.1080/09537329808524310.

[25] A. Rip, Introduction of new technology: making use of recent insights from sociolcmgy and economics of technology, Technol Anal Strateg Manag 7 (1995) 417-432, https://doi.org/10.1080/09537329508524223.

[26] F. Geels, R. Raven, Non-linearity and expectations in niche-development trajectories: ups and downs in dutch biogas development (1973-2003), Technol Anal Strateg Manag 18 (2006) 375-392, https://doi.org/10.1080/09537320600777143.

[27] R. Raven, Strategic niche management for biomass - a comparative study on the experimental introduction of bioenergy technologies in the Netherlands and Denmark, Eindhoven University of Technology, 2005.

[28] L. Coenen, P. Benneworth, B. Truffer, Toward a spatial perspective on sustainability transitions, Res Policy 41 (2012) 968-979, https://doi.org/10.1016/j.respol. 2012.02.014.

[29] R. Raven, Strategic niche management for biomass - a comparative study on the experimental introduction of bioenergy technologies in the Netherlands and Denmark, Eindhoven University of Technology, 2005.

[30] Hoogma RJF. Exploiting technological niches; strategies for experimental introduc tion of electric vehicles. Mumford reeks 5, Enschede; 2000, p. 408. 〈http:// dx.doi.org/ISBN 90-365-1454-1).

[31] L. Coenen, F.J. Díaz López, Comparing systems approaches to innovation and technological change for sustainable and competitive economies: an explorative study into conceptual commonalities, differences and complementarities, J Clean Prod 18 (2010) 1149-1160, https://doi.org/10.1016/j.jclepro.2010.04.003.

[32] P. Hetland, Exploring hybrid communities: telecommunication on trial, University of Oslo, 1996.

[33] M. Borup, N. Brown, K. Konrad, H. Van Lente, The sociology of expectations in science and technology, Technol Anal Strateg Manag 18 (2006) 285-298, https://doi. org/10.1080/09537320600777002.

[34] H. van Lente, A. Rip, Expectations in technological developments: an example of prospective structures to be filled in by agency, in: C. Disco, B. van der Meulen (Eds.), Get. new technol. together stud. mak. sociotechnical order, Walter de Gruyter, Berlin, New York, 1998, pp. 203-230.

[35] M. Borup, N. Brown, K. Konrad, H. Van Lente, The sociology of expectations in science and technology, Technol Anal Strateg Manag 18 (2006) 285-298, https://doi.
[36] F. Geels, R. Raven, Non-linearity and expectations in niche-development trajectories: ups and downs in dutch biogas development (1973-2003), Technol Anal Strateg Manag 18 (2006) 375-392, https://doi.org/10.1080/09537320600777143.

[37] I. Greener, Path dependence, Encycl Br (2017).

[38] A. Klitkou, S. Bolwig, T. Hansen, N. Wessberg, The role of lock-in mechanisms in transition processes: the case of energy for road transport, Environ Innov Soc Transit 16 (2015) 22-37, https://doi.org/10.1016/j.eist.2015.07.005.

[39] Foxon TJ. Technological and institutional ' lock-in' as a barrier to sustainable innovation. London; 2002.

[40] W.B. Arthur, Positive feedbacks in the economy, Sci Am 262 (1990) 92-99, https: //doi.org/10.2307/24996687

[41] M. Junginger, W. van Sark, A. Faaij, Technological learning in the energy sector: lessons for policy, industry and science, Edward Elgar, 2010.

[42] M. Cimoli, Lock-in and specialization (dis)advantages in a structural growth model, in: J. Fagerberg, B. Verspagen, G.N. Von Tunzelmann (Eds.), Dyn. technol. trade growth, Edward Elgar, 1994, pp. 123-144.

[43] A. Klitkou, A. Kaloudis, Scientific versus economic specialisation of business R\&D the case of Norway, Res Eval 16 (2007) 283-298.

[44] A. Klitkou, Demonstration projects in transition processes to sustainable energy and transport, Int J Foresight Innov Policy 11 (2016) 96-125.

[45] A. Fevolden, L. Coenen, T. Hansen, A. Klitkou, The role of trials and demonstration projects in the development of a sustainable bioeconomy, Sustainability 9 (2017) 419, https://doi.org/10.3390/su9030419.

[46] J. Frishammar, P. Söderholm, K. Bäckström, H. Hellsmark, H. Ylinenpää, The role of pilot and demonstration plants in technological development: synthesis and directions for future research, Technol Anal Strateg Manag 27 (2015) 1-18, https:// doi.org/10.1080/09537325.2014.943715.

[47] H. Hellsmark, J. Frishammar, P. Söderholm, H. Ylinenpää, The role of pilot and demonstration plants in technology development and innovation policy, Res Policy 45 (2016) 1743-1761, https://doi.org/10.1016/j.respol.2016.05.005.

[48] A. Fevolden, L. Coenen, T. Hansen, A. Klitkou, The role of trials and demonstration projects in the development of a sustainable bioeconomy, Sustainability 9 (2017) 419, https://doi.org/10.3390/su9030419.

[49] H. Hellsmark, J. Frishammar, P. Söderholm, H. Ylinenpää, The role of pilot and demonstration plants in technology development and innovation policy, Res Policy 45 (2016) 1743-1761, https://doi.org/10.1016/j.respol.2016.05.005

[50] T.P. Hughes, The evolution of large technological systems, in: W.E. Bijker, T.P. Hughes, T.J. Pinch (Eds.), Soc. constr. technol. syst. new dir. sociol. hist. technol., MIT Press, Cambridge, 1987, pp. 51-82, https://doi.org/10.1177/ 030631289019001010

[51] W.B. Arthur, R. Cowan, P. David, J. Farrell, W. Hanson, C. Kindleberger, et al., Competing technologies, increasing returns, and lock-in by historical events, Econ J 99 (1989) 116-131.

[52] J.C. Panzar, R.D. Willig, Economies of scope, Am Econ Rev 71 (1981) 268-272, https://doi.org/10.2307/1815729.

[53] J.C.J.M. van den Bergh, F. Oosterhuis, An evolutionary-economic analysis of energy transitions, in: J.C.J.M. van den Bergh, F.R. Bruinsma (Eds.), Manag. transit to renew. energy theory pract. from local, reg. macro perspect., Edward Elgar, Cheltenham, UK, 2008, pp. 149-173.

[54] M.L. Katz, C. Shapiro, Technology adoption in the presence of network externalities, J Polit Econ 94 (1986) 822-841, https://doi.org/10.2307/1833204.

[55] T.P. Hughes, The evolution of large technological systems, in: W.E. Bijker, T.P. Hughes, T.J. Pinch (Eds.), Soc. constr. technol. syst. new dir. sociol. hist. technol., MIT Press, Cambridge, 1987, pp. 51-82, https://doi.org/10.1177/ 030631289019001010

[56] J. Meadowcroft, What about the politics? Sustainable development, transition management, and long term energy transitions, Policy Sci 42 (2009) 323-340, https://doi.org/10.1007/s11077-009-9097-z.

[57] I. Nygaard, S. Bolwig, The rise and fall of foreign private investment in the jatropha biofuel value chain in Ghana, Environ Sci Policy 84 (2018) 224-234, https: //doi.org/10.1016/j.envsci.2017.08.007.

[58] A.J. Wieczorek, R. Raven, F. Berkhout, Transnational linkages in sustainability experiments: a typology and the case of solar photovoltaic energy in India, Environ Innov Soc Transit 17 (2015) 149-165, https://doi.org/10.1016/j.eist.2015.01.001.

[59] R. Raven, F. Kern, B. Verhees, A. Smith, Niche construction and empowerment through socio-political work. A meta-analysis of six low-carbon technology cases, Environ Innov Soc Transit 18 (2016) 164-180, https://doi.org/10.1016/j.eist. 2015.02.002.

[60] F.W. Geels, F. Kern, G. Fuchs, N. Hinderer, G. Kungl, J. Mylan, et al., The enactment of socio-technical transition pathways: a reformulated typology and a comparative multi-level analysis of the German and UK low-carbon electricity transitions (1990-2014), Res Policy 45 (2016) 896-913, https://doi.org/10.1016/j. respol.2016.01.015

[61] H. Qudrat-Ullah, Modelling and simulation in service of energy policy, Energy Procedia 75 (2015) 2819-2825, https://doi.org/10.1016/j.egypro.2015.07.558.

[62] A. Ford, System dynamics and the electric power industry, Syst Dyn Rev 13 (1997) 57-85, https://doi.org/10.1002/(SICI)1099-1727(199721)13:1 < 57:: AID-SDR117> 3.0.CO;2-B

[63] T.S. Fiddaman, Exploring policy options with a behavioral climate-economy model, Syst Dyn Rev 18 (2002) 243-267, https://doi.org/10.1002/sdr.241.

[64] F.G.N. Li, E. Trutnevyte, N. Strachan, A review of socio-technical energy transition (STET) models, Technol Forecast Soc Change 100 (2015) 290-305, https://doi. org/10.1016/j.techfore.2015.07.017

[65] T. Semertzidis, Can energy systems models address the resource nexus?, Energ Procedia 83 (2015) 279-288, https://doi.org/10.1016/j.egypro.2015.12.182.

[66] A. Herbst, F. Toro, F. Reitze, E. Jochem, Introduction to energy systems modelling, Swiss J Econ Stat 148 (2012) 111-135, https://doi.org/10.1126/science 1111772 
[68] F.W. Geels, B.K. Sovacool, T. Schwanen, S. Sorrell, The socio-technical dynamics of low-carbon transitions, Joule 1 (2017) 463-479, https://doi.org/10.1016/j.joule. 2017.09.018

[69] A. Jonaitis, S. Gudzius, A. Morkvenas, M. Azubalis, I. Konstantinaviciute, A. Baranauskas, et al., Challenges of integrating wind power plants into the electric power system: lithuanian case, Renew Sustain Energy Rev 94 (2018) 468-475, https://doi.org/10.1016/j.rser.2018.06.032.

[70] F.W. Geels, Disruption and low-carbon system transformation: progress and new challenges in socio-technical transitions research and the Multi-Level Perspective, Energy Res Soc Sci 37 (2018) 224-231, https://doi.org/10.1016/j.erss.2017.10. 010 .

[71] Dykes K, Sterman J. Dynamics of innovation and diffusion in large-scale complex technical systems: the case of wind energy. In: Proc 35th int conf syst dyn soc; 2017, p. 1-30.

[72] M. Chesser, J. Hanly, D. Cassells, N. Apergis, The positive feedback cycle in the electricity market: residential solar PV adoption, electricity demand and prices, Energy Policy 122 (2018) 36-44, https://doi.org/10.1016/j.enpol.2018.07.032.

[73] S. Yamani Douzi Sorkhabi, D.A. Romero, G.K. Yan, M.D. Gu, J. Moran, M. Morgenroth, et al., The impact of land use constraints in multi-objective energy-noise wind farm layout optimization, Renew Energy 85 (2016) 359-370, https://doi.org/10. 1016/j.renene.2015.06.026.

[74] M.A. Delucchi, M.Z. Jacobson, Providing all global energy with wind, water, and solar power, Part II: reliability, system and transmission costs, and policies, Energy Policy 39 (2011) 1170-1190, https://doi.org/10.1016/j.enpol.2010.11.045.

[75] R. Gaspar, D. Antunes, A. Faria, A. Meiszner, Sufficiency before efficiency: consumers' profiling and barriers/facilitators of energy efficient behaviours, J Clean Prod 165 (2017) 134-142, https://doi.org/10.1016/j.jclepro.2017.07.075.
[76] F.M. Andersen, M. Baldini, L.G. Hansen, C.L. Jensen, Households' hourly electricity consumption and peak demand in Denmark, Appl Energy 208 (2017) 607-619, https://doi.org/10.1016/j.apenergy.2017.09.094.

[77] J. Palm, Household installation of solar panels - motives and barriers in a 10-year perspective, Energy Policy 113 (2018) 1-8, https://doi.org/10.1016/j.enpol.2017. 10.047.

[78] A. Shomali, J. Pinkse, The consequences of smart grids for the business model of electricity firms, J Clean Prod 112 (2016) 3830-3841, https://doi.org/10.1016/j. jclepro.2015.07.078.

[79] K.W. Costello, R.C. Hemphill, Electric utilities' "death spiral": hyperbole or reality?, Electr J 27 (2014) 7-26, https://doi.org/10.1016/j.tej.2014.09.011.

[80] I.F. Abdin, E. Zio, An integrated framework for operational flexibility assessment in multi-period power system planning with renewable energy production, Appl Energy 222 (2018) 898-914, https://doi.org/10.1016/J.APENERGY.2018.04.009.

[81] L. Gottschamer, Q. Zhang, Interactions of factors impacting implementation and sustainability of renewable energy sourced electricity, Renew Sustain Energy Rev 65 (2016) 164-174, https://doi.org/10.1016/j.rser.2016.06.017.

[82] J.M. Alemany, B. Arendarski, P. Lombardi, P. Komarnicki, Accentuating the renewable energy exploitation: evaluation of flexibility options, Int J Electr Power Energy Syst 102 (2018) 131-151, https://doi.org/10.1016/j.ijepes.2018.04.023.

[83] M.R.M. Cruz, D.Z. Fitiwi, S.F. Santos, J.P.S. Catalão, A comprehensive survey of flexibility options for supporting the low-carbon energy future, Renew Sustain Energy Rev 97 (2018) 338-353, https://doi.org/10.1016/j.rser.2018.08.028.

[84] A. Gravelsins, G. Bazbauers, A. Blumberga, D. Blumberga, S. Bolwig, A. Klitkou, et al., Modelling energy production flexibility: system dynamics approach, Energy Procedia 147 (2018) 503-509, https://doi.org/10.1016/j.egypro.2018.07.060. 